\title{
Strategi Komunikasi Pemasaran Pelaku Usaha Bordir di Tasikmalaya saat Pandemi COVID-19
}

\author{
https://doi.org/10.25008/parahita.v2i1.55
}

\author{
Santi Susanti ${ }^{1}$, Rachmaniar $^{2}$ \\ ${ }^{1,2}$ Universitas Padjadjaran \\ Jl. Raya Bandung-Sumedang Km 21, Sumedang,45363 -Indonesia \\ *Email Korespondensi: santi.susanti@unpad.ac.id
}

\begin{abstract}
This study aims to describe the efforts of Tasikmalaya embroidery entrepreneurs in adapting to COVID-19 pandemic situation, both in producing products and in marketing communications. This research use qualitative method with a case study approach. Data collected through in-depth interviews, observations, literature studies, and document studies relevant to the research topic. To analyse data, we use interactive data analysis technique from Miles and Huberman. Informants of this research are manual embroidery entrepreneurs in the City of Tasikmalaya, who innovate in dealing with the pandemic situation. The results showed that Tasikmalaya embroidery entrepreneurs maintain their business by making innovation of embroidered masks. Every entrepreneurs make embroidered masks tailored to their market share, so embroidered masks produced vary, both in shape, material, and price. Embroidered masks are generating income for the embroidery entrepreneurs, also for resellers. Embroidery entrepreneurs use social media to market their products. Instagram and Facebook are used as communication media in marketing embroidered masks, while Whatsapp is a medium that bridges communication between entrepreneurs and buyers.
\end{abstract}

Keywords: Marketing communication, Tasikmalaya embroidery, COVID-19 pandemic

\begin{abstract}
Abstrak
Penelitian ini bertujuan untuk menggambarkan upaya pelaku usaha bordir Tasikmalaya dalam beradaptasi dengan situasi pandemi COVID-19 saat ini, baik dalam menghasilkan produk maupun komunikasi pemasaran yang dilakukan. Metode yang digunakan dalam penelitian ini adalah kualitatif dengan pendekatan studi kasus. Data dikumpulkan melalui wawancara mendalam, observasi, studi pustaka, serta studi dokumen yang relevan dengan topik penelitian. Teknik analisis data yang digunakan adalah teknik analisis data interaktif dari Miles dan Huberman. Informan penelitian ini adalah para pelaku usaha bordir manual di Kota Tasikmalaya yang berinovasi dalam menghadapi situasi pandemi. Hasil penelitian menunjukkan, para pelaku usaha bordir Tasikmalaya berinovasi untuk memertahankan usahanya dengan membuat masker bordir. Setiap pelaku usaha membuat masker bordir yang disesuaikan dengan pangsa pasar sehingga bentuk masker bordir yang dihasilkan beragam, baik bentuk, bahan, maupun harganya. Masker bordir yang dibuat, selain menghasilkan income bagi pelaku usaha bordir, juga menjadi salah satu sumber penghasilan bagi para reseller. Para pelaku usaha bordir memanfaatkan media sosial dalam memasarkan produknya. Instagram dan Facebook digunakan sebagai media komunikasi dalam memasarkan produk masker bordir, sementara Whatsapp menjadi media yang menjembatan komunikasi pelaku usaha dan pembeli.
\end{abstract}

Kata kunci: Komunikasi pemasaran, bordir Tasikmalaya, pandemi COVID-19

\section{PENDAHULUAN}

Penyebaran COVID-19 membawa perubahan besar dalam kehidupan manusia di seluruh dunia. Beragam sektor yang menyangkut hajat hidup manusia terkena imbas. Pembelajaran tatap muka beralih menjadi pembelajaran jarak jauh yang dilakukan secara online atau dalam jaringan (daring), karyawan yang semula bekerja di kantor (work from office) menjadi bekerja dari rumah (work from home) hingga sektor ekonomi yang menyebabkan banyak perusahaan yang mengurangi jumlah karyawan, hingga terhentinya proses produksi karena tidak sebandingnya keuntungan yang diperoleh dengan biaya produksi yang dikeluarkan. 
Selain perusahaan besar, Usaha Mikro Kecil dan Menengah (UMKM) pun turut merasakan imbas penyebaran COVID-19. Berdasarkan data Kementerian Koperasi sebanyak 1.785 koperasi dan 163.713 pelaku Usaha Mikro Kecil dan Menengah (UMKM) terdampak pandemi COVID-19. Sebagian besar koperasi yang terkena dampak COVID-19 bergerak pada bidang kebutuhan seharihari, sedangkan sektor UMKM yang paling terdampak yakni makanan dan minuman (Amri, 2020).

Penerapan protokol kesehatan 5M, yang terdiri dari memakai masker, mencuci tangan pakai sabun dan air mengalir, menjaga jarak, menjauhi kerumunan, serta membatasi mobilisasi dan interaksi (Virdita, 2021), serta pengurangan berbagai akses ke tempat-tempat umum, mengakibatkan para pelaku usaha yang terbiasa menerapkan penjualan langsung ke konsumen, harus beradaptasi dengan kondisi yang ditimbulkan dari aturan yang diterapkan. Termasuk di dalamnya adalah pelaku usaha bordir di Kota Tasikmalaya yang harus menghadapi kenyataan berkurangnya penjualan produk bordir karena menurunnya daya beli masyarakat. Mereka didorong untuk berpikir kreatif, mencari jalan keluar agar bisa bertahan memasarkan produknya, walaupun dalam kondisi pandemi.

Industri kreatif memiliki daya tahan yang tinggi terhadap perubahan ekonomi global. Ketika kondisi ekonomi dunia mengalami krisis seperti yang terjadi pada tahun 1997, industri kreatif mampu bertahan dari keterpurukan. Beragam inovasi yang dikembangkan dari produk induk, mampu mempertahankan keberlangsungan hidup industri kreatif, seperti yang terjadi pada industri bordir Tasikmalaya. Kreatifitas yang terus dikembangkan dan pengelolaan industri berbasis keluarga, yang menghilangkan keterikatan dalam organisasi ikatan buruh, mampu menjadikan usaha kerajinan bordir Tasikmalaya bertahan hingga sekarang.

Secara garis besar, dari cara pengerjaannya, bordir Tasikmalaya dibagi menjadi dua, yakni bordir manual dan bordir mesin. Bordir manual dikerjakan oleh tenaga manusia menggunakan mesin jahit yang digerakkan oleh kaki yang di kalangan perajin bordir disebut mesin kejek, serta mesin jahit dinamo. Dalam aplikasinya, pola bordir langsung diaplikasikan pada kain tanpa menggunakan alas kain kasa. Kuantitas yang produk yang dihasilkan tidak bisa langsung banyak karena dikerjakan oleh tenaga manusia. Sedangkan bordir mesin dihasilkan oleh mesin bordir yang dioperasikan oleh seorang operator. Hasilnya relatif sama, karena dikerjakan oleh mesin dan jumlah produk yang dihasilkan dalam satu pengerjaan bisa banyak, karena satu dapat mengerjakan 12 lembar kain sekaligus.

Sebelum pandemi, para pelaku usaha bordir manual memiliki beragam cara dalam memasarkan produknya, baik secara offline maupun secara online. Dalam pemasaran secara online, internet memiliki peran signifikan dalam membantu para pelaku usaha memasarkan produknya. Merebaknya pandemi COVID-19 berpengaruh terhadap cara para pelaku usaha memasarkan produknya. Kondisi inilah yang ingin diketahui lebih lanjut dalam penelitian ini.

Maka, berdasarkan latar belakang tersebut, rumusan penelitian ini adalah: "Bagaimana komunikasi pemasaran para pelaku usaha bordir di Tasikmalaya dalam kondisi pandemi COVID-19?"

\section{KERANGKA TEORI}

Teori yang digunakan dalam penelitian ini adalah Teori Tindakan Sosial yang dicetuskan oleh Max Weber, seorang sosiolog dari Jerman. Bagi Weber, tindakan sosial merupakan semua perilaku individu yang memiliki makna subjektif bagi dirinya dan diarahkan kepada tindakan orang lain (Ritzer, 1975). Tindakan di sini bisa terbuka atau tersembunyi, bisa merupakan intervensi positif dalam suatu situasi atau sengaja berdiam diri sebagai tanda setuju dalam situasi tersebut.

Menurut Weber, tindakan bermakna sosial sejauh berdasarkan makna subjektifnya yang diberikan oleh individu atau individu-individu, tindakan tersebut mempertimbangkan perilaku orang lain dan karenanya diorientasikan dalam penampilannya. Bagi Weber, setiap perilaku manusia dilakukan berdasarkan motif-motif tertentu yang ingin dicapainya, baik terhadap 
lawan bicara maupun bagi dirinya sendiri, sesuai dengan maksud komunikasinya.

Terkait dengan penelitian ini, aktifitas pemasaran secara offline maupun online yang dilakukan oleh para pelaku usaha bordir di Kota Tasikmalaya merupakan bentuk tindakan sosial yang memiliki makna tersendiri bagi mereka dan ditujukan kepada orang lain atau pihak yang terlibat dalam aktifitas tersebut untuk dimaknai.

Adapun landasan konseptual dalam penelitian ini adalah komunikasi pemasaran dan komunikasi bermedia. Komunikasi pemasaran merupakan pertukaran informasi dua arah antara pihak atau lembaga yang terlibat dalam pemasaran. Semua pihak yang terlibat dalam proses komunikasi pemasaran melakukan cara yang sama, yaitu mendengarkan, bereaksi, dan berbicara sampai tercipta hubungan pertukaran yang memuaskan.

Pertukaran informasi, penjelasan yang bersifat membujuk, dan negosiasi merupakan seluruh bagian dari proses tersebut. Salah satu bagian dari proses komunikasi pemasaran secara total adalah promosi. Promosi dapat membantu pihak-pihak yang terlibat dalam pemasaran untuk memperbaiki hubungan pertukaran dengan lainnya. Bagian lain dari proses komunikasi adalah umpan balik. Umpan balik ini menunjukkan tentang apa pengaruh dari komunikasi yang dilakukan serta memberi kemungkinan untuk menyesuaikan usaha promosi terhadap keinginan pasar (Asmajasari, 1997).

Komunikasi pemasaran adalah kegiatan komunikasi yang dilakukan oleh pembeli dan penjual, dan merupakan kegiatan yang membantu dalam pengambilan keputusan di bidang pemasaran serta mengarahkan pertukaran agar lebih memuaskan dengan cara menyadarkan semua pihak untuk berbuat lebih baik. Jadi komunikasi pemasaran itu merupakan pertukaran informasi dua arah antara pihak-pihak atau lembaga-lembaga yang terlihat dalam pemasaran (Basu, Swasta, \& Irawan, 2001).

\section{Komunikasi Bermedia}

Komunikasi bermedia (mediated communication) merupakan komunikasi yang menggunakan saluran atau sarana untuk meneruskan suatu pesan kepada komunikan yang jauh tempatnya dan banyak jumlahnya. Salah satu bagian dari komunikasi bermedia adalah computer mediated communication (CMC), yang diartikan sebagai komunikasi manusia yang terjadi melalui penggunaan dua atau lebih perangkat (McQuail, 2005). Bentuk CMC yang paling sering digunakan adalah komunikasi dalam media sosial. Internet memiliki peran besar dalam proses terjadi komunikasi bermedia sosial, karena komunikasi tersebut hanya dapat terjadi jika berada dalam jaringan internet.

"Internet sebagai sebuah bentuk computer mediated communication (CMC), ini berarti memiliki pengertian bahwa proses komunikasi yang dilakukan menggunakan komputer, melibatkan manusia, terjadi pada konteks tertentu dimana didalamnya melibatkan proses pembentukkan media untuk berbagai tujuan" (Tomic dalam Astuti, 2011).

Komunikasi dalam internet selain memiliki konteks komunikasi massa, juga membentuk komunikasi personal dalam jumlah banyak, yaitu pengguna internet dalam melakukan komunikasi berhadapan dengan pengguna lain dalam jumlah banyak yang masing-masing berperan sebagai komunikator dan komunikan. Dengan demikian, sifat komunikasi dalam media sosial berlangsung secara interaktif (Effendi, 2010).

\section{METODE PENELITIAN}

Penelitian ini menggunakan metode kualitatif dengan pendekatan studi kasus, yang menurut Creswell dilakukan oleh peneliti untuk menyelidiki secara cermat suatu program, peristiwa, aktivitas, proses atau sekelompok individu (Mola \& Witarti, 2020).

Pada penelitian ini, studi kasus digunakan untuk menggambarkan komunikasi pemasaran yang dilakukan para pelaku usaha bordir dalam beradaptasi dengan situasi yang ditimbulkan oleh merebaknya COVID-19, agar usahanya dapat bertahan.

Subjek penelitian ini adalah para pelaku usaha bordir di Kota Tasikmalaya yang melakukan penyesuaian dalam pemasaran produk mereka sebagai dampak COVID-19. 
Informan dipilih berdasarkan tujuan atau purposive sampling, agar informan dapat memberikan informasi yang dibutuhkan sesuai maslaah penelitian (Bungin, 2011).

Objek penelitiannya adalah upaya-upaya yang dilakukan para pelaku bordir di Kota Tasikmalaya dalam menghasilkan dan memasarkan produk sebagai bentuk adaptasi terhadap kondisi pandemi yang sedang berlangsung.

Pengumpulan data dilakukan melalui wawancara mendalam kepada para pelaku usaha bordir di Kota Tasikmalaya, observasi, kajian literatur, serta dokumen yang terkait dengan penelitian. Analisis data dilakukan menggunakan teknik analisis data Miles dan Huberman yang berlangsung secara interaktif dan berkesinambungan selama penelitian berlangsung hingga ditarik kesimpulan yang mencakup intisari penelitian. Prosesnya meliputi reduksi data, penyajian data dan kesimpulan (Miles, Huberman, \& Saldana, 2014).

\section{HASIL PENELITIAN}

Bordir merupakan hasil kerajinan masyarakat yang menjadi produk unggulan Tasikmalaya. Hiasan bordir Tasikmalaya adalah serapan dari kebudayaan Cina. Namun berkat tangan terampil dan ulet, maka terciptalah kerudung, kebaya, mukena, tunik, selendang, blus, rok, sprei, sarung bantal, taplak meja, baju gamis, baju koko, kopiah haji, hingga busana sehari-hari yang dihiasi dengan bordir yang menarik.

Keterampilan bordir semakin meluas ke hampir seluruh penduduk kota dan Kabupaten Tasikmalaya dengan cara informal: melalui pendidikan informal dalam keluarga, tetangga, pengusaha kerajinan, dan para pelaku usaha. Para pengusaha kerajinan lebih memilih melatih karyawannya sendiri sesuai dengan kebutuhan produksi yang sedang diminati oleh pasar.

Dengan adanya dukungan Pemerintah Kota Tasikmalaya, para pengusaha bordir mendapatkan lokasi di Pasar Tanah Abang Jakarta sebagai pusat penjualan bordir khas Tasikmalaya. Selain itu pula, pemasarannya ke berbagai pusat perdagangan di Indonesia, seperti Pasar Baru Bandung, Pasar Tegal Gubug Cirebon, Pasar Turi Surabaya, Pasar Klewer Solo, dan lainnya. Juga diekspor ke Malaysia, Singapura, Brunei Darussalam, Saudi Arabia, negara-negara Timur Tengah, Mesir, dan Afrika (Dinas Perindustrian dan Perdagangan Kota Tasikmalaya, 2014).

Berdasarkan prosesnya, pelaku usaha bordir di Kota Tasikmalaya terdiri dari tiga kategori, yaitu pelaku usaha bordir manual yang masih menggunakan mesin jahit tradisional atau mesin kejek dalam proses produksi bordirnya. Jumlah produksi yang dihasilkan tidak banyak, karena proses produksi untuk menghasilkan satu produk bordiran paling cepat tiga hari hingga satu minggu. Tenaga manusia dominan dalam pengerjaan bordir manual ini. Pelaku usaha bordir mesin juga menggunakan mesin bordir komputer otomatis. Satu mesin dapat menghasilkan hingga 12 bordiran sekaligus. Tenaga manusia diperlukan sebagai operator mesin. Pengerjaan bordir dilakukan mesin setelah desain bordir dimasukkan ke dalam komputer. Bordiran mesin umumnya diterapkan pada tas, baju koko, mukena, dan sebagainya.

Para pelaku usaha yang menjadi informan penelitian ini adalah pelaku usaha bordir manual yang menjalankan komunikasi pemasaran produknya secara offline dan online. Produk yang mereka hasilkan, merupakan produk fashion yang terdiri dari beragam jenis. Berdasarkan pengamatan, produk yang umumnya di jual adalah mukena, blazer, outer, tempat tisu, tas, dan pernak-pernik lainnya yang dibordir.

Berdasarkan penuturan pada informan, pemasaran produk secara offline dilakukan melalui penjualan langsung di gerai pelaku usaha, penjualan langsung kepada konsumen, dan pameran, di dalam maupun di luar negeri. Para pelaku usaha yang melakukan pejualan langsung di gerainya, antara lain Dawalul Embroidery, Mia Bordir, Rumah Kayu Bordir, Katumbiri, Alumazra Bordir, Ariesta Bordir, Yuyun Bordir, Mins Bordir, serta Dian \& Rossy Bordir. Dengan cara penjualan langsung di gerai, peminat dapat langsung datang melihat koleksi yang tersedia. Jika berminat bisa langsung melakukan transaksi. Beberapa di antaranya melayani pembuatan produk bordir sesuai pesanan pembeli.

Cara pemasaran dengan menjual langsung di gerai merupakan bentuk penerapan 
bauran pemasaran yang terdiri dari empat komponen, yakni, Product (produk), Price (harga), Place (tempat, termasuk juga distribusi) dan Promotion (promosi). Para pembeli dapat melihat produk dan harga dengan mendatangi tempat penjualnya langsung. Selain itu, bagi pemilik usaha, gerai merupakan tempat promosi bagi beragam produk lainnya yang diproduksi. Hal tersebut diharapkan menarik perhatian konsumen sehingga menambah pembelian produk selain produk utama yang dicarinya.

Bentuk pemasaran lainnya adalah penjualan langsung kepada konsumen, dilakukan oleh Dian \& Rossy Bordir. Nanang Yoyo selaku pemilik usaha, menyebutkan sebelum pandemi, secara rutin seminggu sekali, setiap Kamis, ia selalu memasarkan produknya di Pusat Penjualan Bordir Khas Tasikmalaya di Pasar Tanah Abang. Penghasilan yang diperoleh dari penjualan langsung disebutnya bagus, karena dengan materi produk yang dijualnya adalah bordir manual, maka praktis tidak begitu banyak saingan. Karena sebagian besar para pedagang bordir di Pasar Tanah Abang menjual produk bordir yang dihasilkan oleh mesin. Kondisi pandemi memaksa Nanang untuk menghentikan sementara penjualan langsung di Pasar Tanah Abang. Ia pun berharap pada pembelian produk secara online.

Pameran merupakan salah satu bentuk pemasaran yang dilakukan pelaku usaha bordir di Tasikmalaya. Beberapa pelaku usaha yang sering mengikuti pameran yakni Dawalul, Mia Bordir, Rumah Kayu Bordir. Ketiganya mendapatkan kesempatan untuk sering mengikuti pameran yang diselenggarakan oleh Bank Indonesia, karena mereka menjadi UMKM binaan Bank Indonesia.

Sementara itu Alumazra Bordir, selain mengikuti pameran yang diselenggarakan oleh Dinas UMKM Perindag Kota Tasikmalaya atau institusi di lainnya, juga aktif mengikuti fashion show yang diselenggarakan di kota-kota besar di Indonesia. Ini merupakan salah satu bentuk promosi produk yang dihasilkan oleh Alumazra Bordir.

Kondisi pandemi telah mengubah pola pemasaran yang selama ini dilakukan. Seluruh informan menunda sementara waktu pemasaran produk secara offline kepada pembeli. Mereka saat ini, fokus pada penjualan secara online, dengan bantuan media sosial.

Kehadiran internet menjadikan penjualan melalui online menjadi lebih mudah. Sebelum pandemi, informan telah melakukan penjualan secara online, melalui Whatsapp (WA), Facebook, dan Instagram.

Dawalul, misalnya, mengandalkan Instagram untuk penjualan secara online. Menurut Eva Dawalul, selaku pemilik usaha, Instagram sangat membantu dalam penjualan secara online, karena dapat menayangkan teks, gambar, maupun konten audio visual yang berkaitan dengan produk. Melalui Instagram, komunikasi pemasaran yang dilakukan oleh Dawalul adalah menampilkan produk, baik yang dipakai oleh model maupun figure terkenal, maupun menampilkan video yang menggambarkan proses produksi, maupun saat berpameran. Cara berkomunikasi seperti itu dilakukan memberikan kepercayaan kepada calon konsumen nama perusahaan serta produk-produk yang ditampilkan dalam Instagram Dawalul.

Demikian pula dengan Alumazra bordir, yang memasarkan produk secara online melalui Instagram dan WA sebagai bentuk komunikasi lanjutan dengan pembeli. Namun, dalam pemasaran melalui online, Anggi, pemilik usaha, tidak banyak mengekspos hasil karyanya. Hal itu dilakukannya untuk menghindari plagiasi model produk yang ditampilkannya, karena ia pernah mengalami hal tersebut beberapa kali. Anggi hanya mengeluarkan produknya saat fashion show maupun pameran.

Sementara itu, Rini Sundari, pemilik Katumbiri Sulam Perca dan Bordir menggunakan media sosial Instagram dan Facebook dalam memasarkan produknya secara online, yang dimulai sejak tahun 2014. Sebagian besar komunikasi dilakukan melalui Whatsapp. Umumnya bentuk komunikasi melalui WA, terjalin dengan konsumen lama, atau yang datang ke galeri sebelumnya. Rini menyebutkan, pembelian lebih banyak melalui media sosial dibandingkan membeli langsung, dengan perbandingan 60-40. Pengelolaan media sosial dipercayakan kepada orang yang ditunjuk sebagai admin.

Para pelaku usaha menghindari penjualan melaui market place, karena terkendala 
ketersediaan barang. Alasannya, produk bordir manual tidak bisa dihasilkan secepat bordir mesin, sementara di market place produk harus selalu tersedia, karena itu, para pelaku bordir manual lebih nyaman dengan kondisi saat ini: menjual secara online melalui media sosial.

Bagi para pelaku usaha bordir manual, yang menjadi informan penelitian ini, media sosial lebih diperlukan sebagai media komunikasi, bukan sebagai media pemasaran utama. Bagi mereka, media pemasaran yang utama adalah pameran dan berjualan langsung di galeri.

Menurut Astari dari Mia Bordir, market place hanya cocok bagi produk massal, karena pangsa pasarnya diperuntukkan bagi siapapun. Sedangkan bagi produk bordir yang dihasilkan melalui mesin jahit manual, dari pemesanan hingga barang jadi, dibutuhkan waktu paling tidak dua minggu. Selain itu, harga barang pun relatif mahal dan yang membutuhkannya adalah orang-orang yang mencintai seni bordir. Astari pernah mencoba memasarkan produknya melalui market place, namun sudah lebih dari satu tahun, belum ada peminatnya.

Menurut Astari, media sosial yang dirasa sesuai dengan karakter bordir adalah Instagram dan Whatsapp, karena sifat dari kedua media tersebut bisa privat bisa juga sosial. Keduanya bisa menjadi media penyambung antara pelaku usaha dengan pelanggan yang dipertemukan dalam suatu pameran.

Merebaknya COVID-19 menghentikan seluruh aktifitas pemasaran produk bordir manual secara offline. Pelaku usaha didorong untuk memunculkan kreatifitas baru dalam produk-produk yang dihasilkannya dalam upaya menyikapi kondisi pandemic yang memaksa beragam aktifitas menjadi terbatas.

Pada umumnya, kreasi para pelaku usaha dalam memertahankan usahanya adalah membuat masker bordir dari kain. Kreasi bordir dari para pelaku usaha muncul pada tahun 2000, beberapa waktu setelah COVID-19 diberitakan merebak ke seluruh dunia. Masker yang diproduksi bervariasi, baik dari model bordir, bahan kain yang digunakan, serta harga jual maskernya.

Dawalul Bordir, Mia Bordir dan Alumazra Bordir, membuat masker untuk pangsa pasar menengah atas, dengan harga jual di atas Rp 50 ribu. Sementara itu, Rumah Kayu Bordir, Katumbiri, Ariesta Bordir, Yuyun Bordir, dan Mins Bordir memproduksi masker dengan harga lebih terjangkau, tanpa mengurangi kualitas yang dihasilkan. Masker yang dihasilkan merupakan hasil kreasi dari pemilik usaha sebagai bentuk adaptasi produksi terhadap kondisi pandemi.

Berdasarkan penuturan para pelaku usaha, produk masker mereka sangat membantu mengatasi berkurangnya pembelian produk bordir di luar masker. Bahkan Eva Dawalul menyebut jika produknya dijual pula oleh para reseller. Ia mengaku senang, karena selain menjadi sumber penghasilan bagi perusahaannya, masker bordir pun dapat menjadi penghasilan bagi para reseller produk maskernya.

Penjualan produk masker selain melalui para reseller, dilakukan pula melalui media sosial. Sebagian besar adalah Instagram. Dawalul dan Mia Bordir memproduksi masker cukup banyak secara berseri yang ditampilkan di Instagram. Setiap model di beri angka untuk memudahkan konsumen dalam memesan masker bordir yang diinginkannya. Bagi para pelaku usaha bordir, Instagram sangat membantu dalam memasarkan produk masker bordir yang dihasilkan. Beragam model masker yang ditampilkan dalam Instagram membentu pembeli untuk memilih masker bordir yang diinginkan.

Adaptasi dan inovasi merupakan kunci bagi pelaku industri kreatif di Jawa Barat. Dwinita Larasati dari Dewan Pengarah Komite Ekonomi Kreatif dan Inovasi (Kreasi) Jawa Barat mengatakan, Jabar memiliki potensi sangat memadai untuk mengembangkan industri kreatif di era adaptasi kebiasaan baru. Kekayaan intelektual, intelegensi dan daya cipta yang menjadi akar industri kreatif menjadikannya sebagai sektor paling prospektif dalam menghadapi kondisi pandemi. Penjualan secara daring dan e-commerce pun, sebagai bagian dari industri kreatif diperkirakan akan terus berkembang seiring berkembangnya industri kreatif (Ginanjar, 2020) 


\section{KESIMPULAN}

Pandemik COVID-19 yang melanda dunia memengaruhi berbagai sektor kehidupan manusia, termasuk ekonomi kreatif di Jawa Barat. Sebagai industri yang berbasiskan kreatifitas, para pelaku usaha dituntut daya imajinasi untuk menghasilkan produk yang dapat membuat mereka tetap bertahan dalam situasi pandemi saat ini. Anjuran pemerintah mengenakan masker menjadi satu pemicu para pelaku usaha bordir di Kota Tasikmalaya untuk berinovasi dengan membuat masker bordir. Beragam motif yang dibordir pada masker menjadikan masker memiliki fungsi ganda, yakni sebagai penutup hidup dan mulut juga sebagai fashion.

Komunikasi pemasaran yang dilakukan oleh para pelaku usaha bordir dalam memasarkan maskernya dilakukan melalui online, dengan memanfaatkan media sosial seperti Instagram, Facebook, serta Whatsapp, juga melalui reseller. Instagram dan Facebook berperan sebagai media promosi produk masker bordir, sedangkan Whatsapp lebih banyak diperlukan sebagai media komunikasi antara pelaku usaha dengan pembeli.

Kesimpulan penelitian ini adalah media sosial dirasakan sangat berperan dalam menjembatani komunikasi penjual dalam memasarkan produknya kepada masyarakat.

\section{Daftar Pustaka}

Amri, A. (2020). Dampak Covid-19 terhadap UMKM Di Indonesia. BRAND Jurnal Ilmiah Manajemen Pemasaran, 2(1), 123-131. Retrieved from https://ejournals.umma.ac.id/index.php/brand/article/view/605

Asmajasari, M. (1997). Studi Periklanan dalam Perspektif Komunikasi. Astuti, P. A. A. dkk. (2011). Remaja Digital: Learn, Play, Socialize, Participate. Surakarta. Basu, Swasta, \& Irawan. (2001). Managemen Pemasaran Modern. Yogyakarta: Liberty. Bungin, M. B. (2011). Penelitian Kualitatif. Jakarta: Kencana Prenada.

Effendi, M. (2010). Peranan Internet sebagai Media Komunikasi. Komunika, Jurnal Dakwah dan Komunikasi, 4(1), 130-142.

Ginanjar, A. (2020). Adaptasi dan Inovasi, Kunci Keberhasilan Industri Kreatif di Era AKB. Retrieved July 20, 2021, from https://m.ayobekasi.net website: https://m.ayobekasi.net/read/2020/06/11/6377/adaptasi-dan-inovasi-kuncikeberhasilan-industri-kreatif-di-era-akb

McQuail, D. (2005). McQuail's Mass Communication Theory (5th Edition). London: Sage Publication Ltd.

Miles, M. B., Huberman, A. M., \& Saldana, J. (2014). Qualitative Data Analysis A Methods Sourcebook Edition 3 (3rd ed.). California: SAGE Publications, Inc.

Mola, M. S. R., \& Witarti, D. I. (2020). Komunikasi Pemasaran Terpadu dalam Pengembangan Pariwisata Ende Studi Kasus: Festival Danau Kelimutu. Communication, 11(1), 1-13. Retrieved from http://journal.budiluhur.ac.id/index.php/comm/article/view/1004

Ritzer, G. (1975). Sociology: A Multiple Paradigm Science. Boston: Allyn and Bacon.

Virdita, R. (2021). Inilah 5M untuk pencegahan COVID-19 dan bedanya dengan 3M serta 3T. Retrieved July 20, 2021, from https://kesehatan.kontan.co.id website: https://kesehatan.kontan.co.id/news/inilah-5m-untuk-pencegahan-COVID-19-danbedanya-dengan-3m-serta-3t 